\title{
Ectopic Acth-Producing Pulmonary Carcinoid: A Rare Case of Simulating the Cushing's disease
}

\author{
Reza Mohamad hosseinzade Davatgari ${ }^{1}$, Soghra Rabizadeh ${ }^{1}$, Azin Ghamari ${ }^{2}$, Alireza Esteghamati ${ }^{1}$, Manouchehr Nakhjavani ${ }^{1 *}$ \\ ${ }^{1}$ Endocrinology and Metabolism Research Center (EMRC), Vali-Asr Hospital, Tehran University of Medical Sciences, Tehran, Iran \\ ${ }^{2}$ Growth and development research center,childrens medical center, Tehran University of Medical Sciences, Tehran, Iran
}

*Corresponding author: Manouchehr Nakhjavani, 1Endocrinology and Metabolism Research Center (EMRC), Vali-Asr Hospital, Tehran University of Medical Sciences, Tehran, Iran

Received date: February 16, 2020; Accepted date: March 09, 2020; published date: March 13,2020

Citation: Reza Mohamad hosseinzade Davatgari, Soghra Rabizadeh, Azin Ghamari, Alireza Esteghamati, Manouchehr Nakhjavani (2020) Ectopic Acth-Producing Pulmonary Carcinoid: A Rare Case of Simulating the Cushing's disease. J Clinical Research and Reports, 3(4); DOI:10.31579/26901919/044

Copyright: () 2020 Manouchehr Nakhjavani. This is an open access article distributed under the Creative Commons Attribution License, which permits unrestricted use, distribution, and reproduction in any medium, provided the original work is properly cited.

\begin{abstract}
:
Excess amounts of blood glucocorticosteroids, either exogenous or endogenous, results in Cushing's syndrome (CS). the current study presents a 45-year-old man, ACTH dependent Cushing's syndrome. The basal cortisol and urine free cortisol level were significantly suppressed following high dose dexamethasone suppression test and pituitary MRI showed microadenoma with a size of less than $6 \mathrm{~mm}$. After bilateral inferior petrosal sinus sampling, we investigated the ectopic source of ACTH production. The computed tomography revealed a mediastinal lymph node, and the whole body octreotide scan revealed octreotide avid lesion in the medial aspect of the left lung. The patient underwent left lung lobectomy and the pathological study indicated the carcinoid tumor of the left lung.
\end{abstract}

Keywords: Adrenocorticotropic; Ectopic Cushing's syndrome; lung carcinoid tumor

\section{Introduction:}

Excess amounts of blood glucocorticosteroids, either exogenous or endogenous, results in Cushing's syndrome (CS)[1]. In about $10 \%$ of cases with Adrenocorticotropic hormone (ACTH) dependent Cushing's syndrome, hypercortisolism develops due to hypersecretion of ACTH from a non-pituitary neuroendocrine tumor (EAS) [2-5]. The association of CS with ectopic adrenocorticotropic hormone (ACTH) secretion was described in $1962[6,7]$. This study is going to describe a rare case of CS due to an ectopic ACTH producing tumor presented simulating to Cushing disease ( pituitary origin) according to the clinical and laboratory findings.

\section{Case presentation:}

A 45-year-old man was referred to our institution due to fatigue, generalized bone pain, proximal muscle weakness, weight gain, facial swelling since one year before the visit. The past medical history, past surgical history and family history, was unremarkable. There was no history of drug consumption, as well. Initial physical examination revealed central obesity, moon face, facial plethora, lower extremity proximal muscle weakness (4/5), positive Govern sign, violaceous striae (width $>1 \mathrm{~cm}$ ) in abdomen \& flanks, blood pressure of $135 / 85 \mathrm{mmHg}$, pulse rate of 75 beats per minute, weight of 72 kilograms, height of 175 centimeters and body mass index of $23.5 \mathrm{Kg} / \mathrm{m}^{2}$. Laboratory tests: sodium: $140 \mathrm{meq} / \mathrm{lit}, \mathrm{K}: 3.8 \mathrm{meq} / \mathrm{lit}, \mathrm{FBS}: 110 \mathrm{mg} / \mathrm{dl}$, creatinine: $0.8 \mathrm{mg} / \mathrm{dl}$, bicarbonate: $24 \mathrm{meq} / \mathrm{lit}$.
Urine free cortisol was high on two occasions (1240 and $1465 \mu \mathrm{g} / 24 \mathrm{~h}$ ) and due to a very high level of urine free cortisol, the low dose dexamethasone suppression test was not performed. ACTH level was 125 $\mathrm{pg} / \mathrm{ml}$. further evaluation including high dose dexamethasone suppression test (HDDST)( $2 \mathrm{mg}$ dexamethasone every 6 hours for 48 hours) and pituitary MRI were done. The morning serum cortisol and urine free cortisol (UFC) levels were suppressed more than $90 \%$ from baseline following high dose dexamethasone suppression test (HDDST) (table 1).

\begin{tabular}{|c|c|c|c|c|}
\hline $\begin{array}{c}\text { UFC } \\
\text { (base) }\end{array}$ & $\begin{array}{c}\text { UFC } \\
\text { (HDDST) }\end{array}$ & $\begin{array}{c}\text { Cortisol } \\
\text { (base) }\end{array}$ & $\begin{array}{c}\text { Cortisol } \\
\text { (HDDST) }\end{array}$ & ACTH \\
\hline $\begin{array}{c}1465 \\
\mu \mathrm{g} / 24\end{array}$ & $46 \mu \mathrm{g} / 24 \mathrm{~h}$ & $20.6 \mu \mathrm{g} / \mathrm{dl}$ & $1.75 \mu \mathrm{g} / \mathrm{dl}$ & $125 \mathrm{Pg} / \mathrm{ml}$ \\
\hline
\end{tabular}

Table 1: UFC and serum morning cortisol measured at baseline and after high dose dexamethasone suppression test.

UFC: urine free cortisol; HDDST: high dose dexamethasone suppression test; ACTH: adrenocorticotropic hormone.

The pituitary magnetic resonance imaging (MRI) indicated a $2.8 \mathrm{~mm}$ microadenoma in the midline of pituitary gland (figure 1). Because the size of microadenoma was less than $6 \mathrm{~mm}$, bilateral inferior petrosal sinus sampling (BIPSS) was done. The results were presented in table 2. Results of BIPSS showed no central to peripheral gradient in ACTH and pituitary origin for ACTH excess was ruled out. 


\begin{tabular}{|c|c|c|c|c|c|}
\hline \multirow{2}{*}{$\begin{array}{c}\text { ACTHACTH } \\
(\mathbf{P g} / \mathrm{ml})\end{array}$} & \multicolumn{2}{|c|}{ IPS } & \multirow[t]{2}{*}{ Peripheral } & \multicolumn{2}{|c|}{ IPS/Peripheral ratio } \\
\hline & Right & Left & & Right & Left \\
\hline-15 & 83.9 & 79.9 & 80.1 & 1.04 & 0.99 \\
\hline-10 & 89.9 & 90.2 & 79.3 & 1.13 & 1.13 \\
\hline-5 & 84.1 & 80.8 & 77.8 & 1.08 & 1.03 \\
\hline $\mathbf{0}$ & 87.2 & 85 & 74.9 & 1.16 & 1.13 \\
\hline+3 & & 148 & 92.8 & & 1.59 \\
\hline+5 & 215 & 211 & 154 & 1.39 & 1.37 \\
\hline+8 & 239 & 242 & 208 & 1.14 & 1.16 \\
\hline+10 & 239 & 248 & 207 & 1.15 & 1.19 \\
\hline+15 & 223 & 229 & 189 & 1.17 & 1.21 \\
\hline Prolactin(ng/dl) & 16.9 & 16.3 & 3.2 & & \\
\hline
\end{tabular}

Table 2: The laboratory results following inferior petrosal sinus sampling (IPSS) ACTH: Adrenocorticotropic hormone; IPS: inferior petrosal sinus;

For the investigation of the source of ectopic Cushing's syndrome The computed tomography (CT) scan of the chest and abdominopelvic was performed. CT scan indicated a mediastinal lymph node and a nodule located in the left lung. The whole body sintigraphy scan with 8 mci TC$99 \mathrm{~m}$ - octerotide revealed octreotide avid lesion in the medial aspect of the left lung.

The left lung lobectomy was performed and pathological assessments indicated a typical carcinoid tumor. The immunohistochemistry study of tumor and lymph node was positive for ACTH, which was in favor of ectopic ACTH-producing Cushing's syndrome. The cortisol level following the left lung lobectomy was low and the patient received hydrocortisone.

\section{Discussion:}

This study presents a rare case of ectopic ACTH-producing Cushing's syndrome due to pulmonary carcinoid. The srum cortisol level and UFC were suppressed significantly ( more than 90\%) on the high dose dexamethasone suppression test (HDDST), which is more favorable for pituitary cause of hypercortisolism (cushing disease) (table1). Also, the pituitary MRI showed a microadenoma with a size less than $6 \mathrm{~mm}$ (figure1).

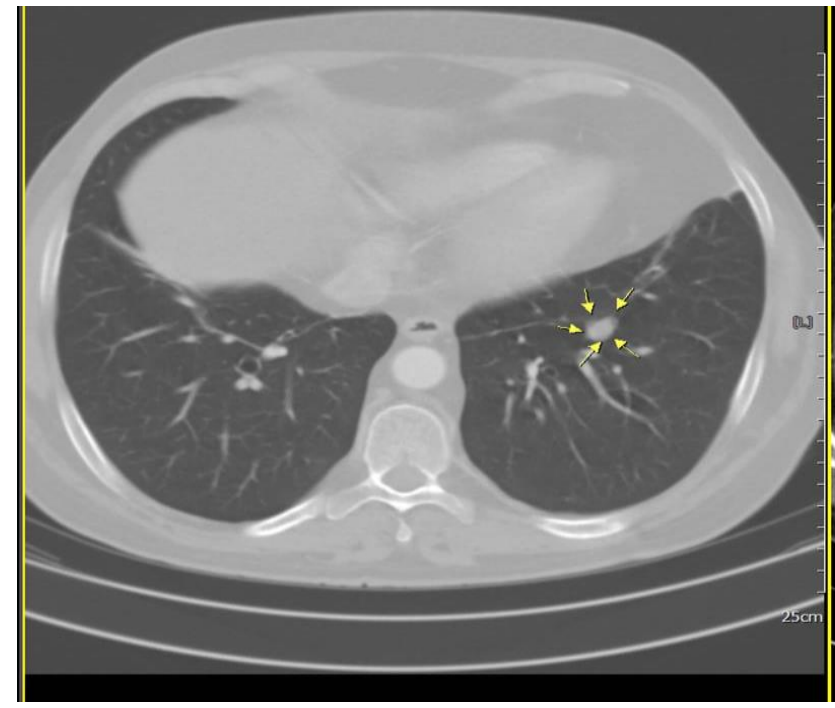

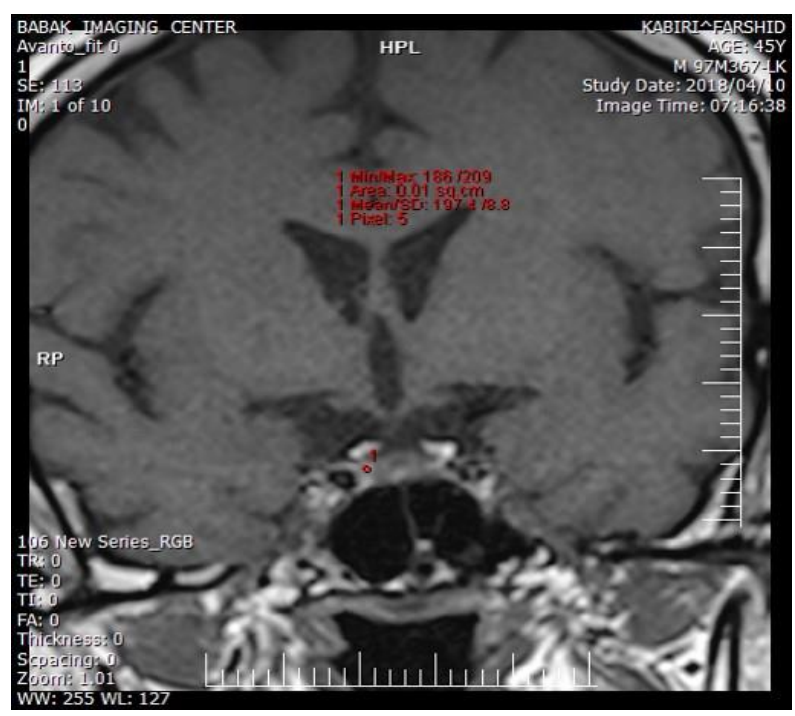

Figure 1: The pituitary magnetic resonance imaging (MRI) indicated a $2.8 \mathrm{~mm}$ microadenoma of the pituitary gland.

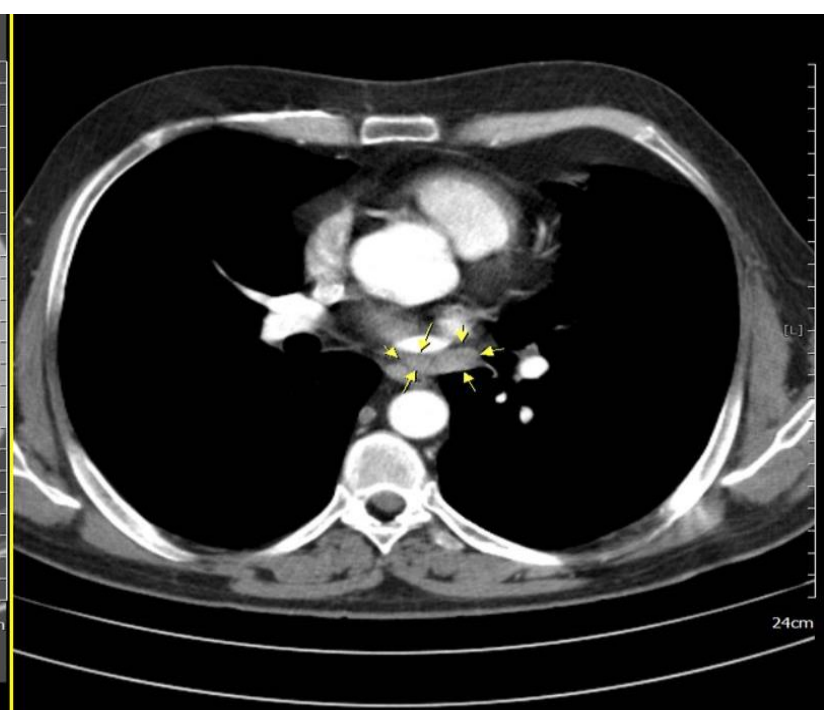

Figure 2: Contrast inhanced computed tomography of the chest : a mediastinal lymph node (right) and a nodule in the left lower lobe (left). 


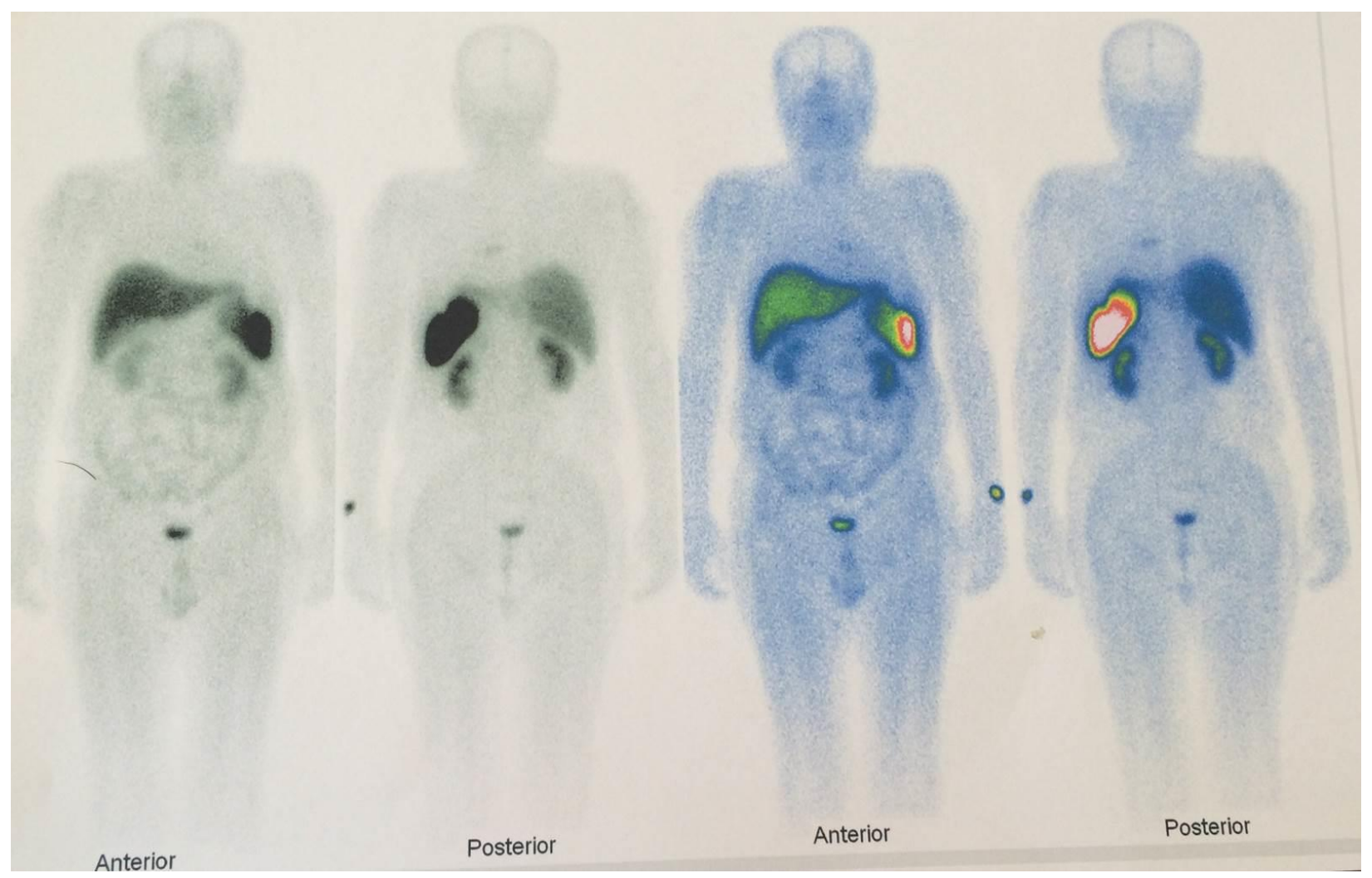

Figure3: Whole body octerotide scan: an octreotide avid lesion in the medial aspect of the left lung.

Therefore, the BIPSS was performed which revealed the ectopic origin of the ACTH production (EAS). The chest CT scan showed a mediastinal lymph node and a nodule in the left lung and whole body octreotide scan confirmed the diagnosis.

The suppression of the serum cortisol level after the HDDST has commonly occurred in Cushing disease [8]. The point that makes this case interesting was that although HDDST was in favor of Cushing disease and a microadenoma was found in pituitary MRI , the diagnostic evaluations, followed by diagnostic algorithms, led to the diagnosis of the ectopic ACTH producing carcinoid.

The ACTH-dependent CS results from ectopic ACTH secretion is rare, but is severe and is associated with elevated mortality and morbidity in cases left untreated. It is mostly due to neuroendocrine tumors located somewhere other than the pituitary gland. It could be originated from lung small cell carcinoma, larynx, esophagus, urinary bladder and urogenital system $[9,10]$. Nearly half of the cases comprise small cell carcinoma and carcinoid of the lung [11]. It castles the light on the point that it is better to assess the lungs first for finding the ectopic source. The most common malignancy which is associated with EAS is considered bronchopulmonary carcinoids [12]. These patients usually have not pulmonary symptoms; moreover, sometimes these tumors are too small to be detected on imagining modalities but they are hormonally active [12] [13]; therefore, the diagnosis could be delayed months to years [13] $[14]$.

The presented patient did not have any pulmonary symptoms and the diagnosis of the carcinoid tumor of the lung was definitive one year following the appearance of the symptoms of hypercortisolism.
Imaging and hormonal assessments are able to differentiate the Cushing disease $(\mathrm{CD})$ and EAS; although there are still difficulties in this regard for some patients, especially whose pathologic lesion was not detected by pituitary MRI. This is not even uncommon for patients diagnosed with CD; approximately $40-50 \%$ of patients diagnosed with CD surgically had no abnormal MRI $[15,16]$; on the other hand, $10 \%$ of healthy subjects have pituitary incidentaloma on MRI evaluations [17], which higher prevalence could be anticipated as more sophisticated MRI equipment emerge. It can be concluded that the differentiation between pituitary incidentaloma and EAS could be a challenging issue. Other tests such as high dose dexamethasone suppression test (HDDST) is an acceptable tool for differentiating the conditions; although there is still margin of uncertainty for the accurate localization of the pathologic lesion; in contrast to other diagnostic modalities, bilateral inferior petrosal sinus sampling (BIPSS) is a more powerful modality for differentiating the CD and EAS. BIPSS is able to differentiate the pituitary-origin hypercortisolism from non-pituitary origin [18], but it cannot localize the site of the ectopic lesion. The BIPSS in this patient was in favor of EAS and further imaging studies, including chest CT scan which indicated mediastinal lymph node and the whole body octreotide scan indicated abnormal mass in the left lung.

\section{References:}

1. Lou F, Sarkaria I, Pietanza C, Travis W, Roh MS, Sica G et al. Recurrence of pulmonary carcinoid tumors after resection: implications for postoperative surveillance. 2013;96(4):115662.

2. Karageorgiadis AS, Papadakis GZ, Biro J, Keil MF, Lyssikatos $\mathrm{C}$, Quezado MM et al. Ectopic adrenocorticotropic hormone and corticotropin-releasing hormone co-secreting tumors in children and adolescents causing cushing syndrome: a 
diagnostic dilemma and how to solve it. The Journal of Clinical Endocrinology \& Metabolism. 2015;100(1):141-8.

3. Nakhjavani M, Amirbaigloo A, Rabizadeh S, Rotondo F, Kovacs K, Ghazi AA. Ectopic cushing's syndrome due to corticotropin releasing hormone. Pituitary. 2019;22(5):561-8.

4. Shahani S, Nudelman RJ, Nalini R, Kim H-S, Samson SL. Ectopic corticotropin-releasing hormone (CRH) syndrome from metastatic small cell carcinoma: a case report and review of the literature. Diagnostic pathology. 2010;5(1):56.

5. Suda T, Tozawa F, Dobashi I, Horiba N, Ohmori N, Yamakado $\mathrm{M}$ et al. Corticotropin-releasing hormone, proopiomelanocortin, and glucocorticoid receptor gene expression in adrenocorticotropin-producing tumors in vitro. The Journal of clinical investigation. 1993;92(6):2790-5.

6. Liddle GW, Nicholson WE, Island DP, Orth D, Abe K, Lowder SJRPHR. Clinical and laboratory studies of ectopic humoral syndromes. 1969;25:283-3.

7. MEADOR CK, LIDDLE GW, ISLAND DP, NICHOLSON WE, LUCAS CP, NUCKTON JG et al. Cause of Cushing's syndrome in patients with tumors arising from "nonendocrine" tissue. 1962;22(7):693-703.

8. Melmed S, Polonsky KS, Larsen PR, Kronenberg HM. Williams textbook of endocrinology. Elsevier Health Sciences; 2015.

9. Walenkamp AM, Sonke GS, Sleijfer DTJCtr. Clinical and therapeutic aspects of extrapulmonary small cell carcinoma. 2009;35(3):228-36.

10. Feffer JB, Branis NM, Albu JBJFie. Dual paraneoplastic endocrine syndromes Heralding onset of extrapulmonary small Cell Carcinoma: a Case Report and Narrative Review. 2018;9:170.
11. Beuschlein F, Hammer GD. Ectopic pro-opiomelanocortin syndrome. Endocrinology and metabolism clinics of North America. 2002;31(1):191-234.

12. Dall'Asta C SL, Castellani M, Ambrosi B. Difficulties, of idatoeA-pt, 2002;21:149-151 tcEJCS.

13. Limper AH, Carpenter PC, Scheithauer B, Staats BA. The Cushing syndrome induced by bronchial carcinoid tumors. Annals of internal medicine. 1992;117(3):209-14.

14. Deb SJ, Nichols FC, Allen MS, Deschamps C, Cassivi SD, Pairolero PC. Pulmonary carcinoid tumors with Cushing's syndrome: an aggressive variant or not? The Annals of thoracic surgery. 2005;79(4):1132-6; discussion -6.

15. Findling JW, Raff H. Cushing's Syndrome: important issues in diagnosis and management. The Journal of clinical endocrinology and metabolism. 2006;91(10):3746-53.

16. Zampetti B, Grossrubatscher E, Dalino Ciaramella P, Boccardi E, Loli P. Bilateral inferior petrosal sinus sampling. Endocrine connections. 2016;5(4):R12-25.

17. Hall WA, Luciano MG, Doppman JL, Patronas NJ, Oldfield EH. Pituitary magnetic resonance imaging in normal human volunteers: occult adenomas in the general population. Annals of internal medicine. 1994;120(10):817-20.

18. Oldfield EH, Doppman JL, Nieman LK, Chrousos GP, Miller DL, Katz DA et al. Petrosal sinus sampling with and without corticotropin-releasing hormone for the differential diagnosis of Cushing's syndrome. The New England journal of medicine. 1991;325(13):897-905.
This work is licensed under Creative Commons Attribution 4.0 License

\section{To Submit Your Article Click Here: Submit Manuscript}

DOI: $10.31579 / 2690-1919 / 044$
Ready to submit your research? Choose Auctores and benefit from:

* fast, convenient online submission

* rigorous peer review by experienced research in your field

* rapid publication on acceptance

* authors retain copyrights

* unique DOI for all articles

* immediate, unrestricted online access

At Auctores, research is always in progress.

Learn more www.auctoresonline.org/journals/journal-of-clinicalresearch-and-reports 